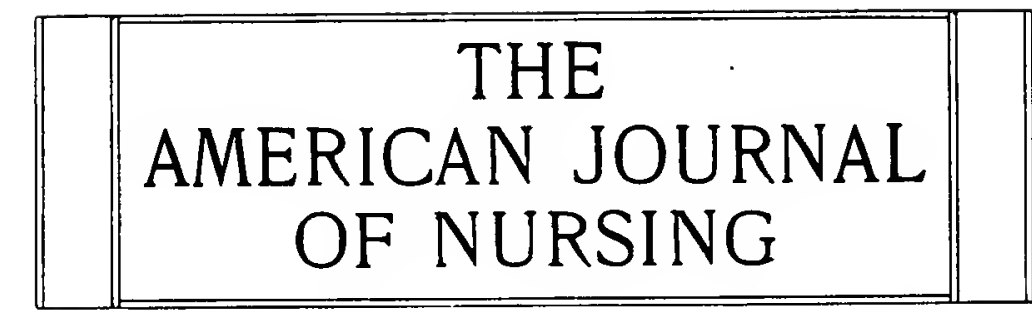

\begin{tabular}{l|l|l}
\hline \hline VOL. II & NOVEMBER, 190I & NO. 2 \\
\hline
\end{tabular}

\title{
THE OPPORTUNITY AND RESPONSIBILITY OF THE GRADUATE NURSE OF TO-DAY
}

[The following papers were read at the Congress in Buffalo on the afternoon of Thursday, September 19, 1801. The discussion was curtailed because of the early adjournment on account of the funeral of President McKinley.-ED.]

FIRST PAPER

BX KATHERINE DEWITT

Illinols Tralning-School, Chlcago

THE question of opportunity is not a difficult one. The problems which are facing the nursing world are of such importance, are so much in evidence, and are so insistent that a nurse must be blind and deaf who is ignorant of their existence. The thinkers and workers in the nursing profession all over the world are considering the questions of registration, preliminary training, teachers' courses, uniformity of education, combinations of small or special hospitals, post-graduate work, and the maintenance of alumnæ associations. These and similar themes press closely upon us and demand attention. The difficulty lies in the question of responsibility. Who should bear it?

Graduate nurses may be divided into three classes-those who hold hospital positions, those who do private nursing, and those who have married or have for other reasons retired into private life. Their interest in nursing affairs dwindles as they get farther away in space or time from their place of training. Very few who have given up nursing work retain more than a vague interest in our doings. Those who do, those who hold the motto, "Once a nurse, always a nurse," are the most valuable of workers. They often have more leisure for thinking, more 
time to devote to official responsibilities, and a broader view of affairs than those who are still in the ranks.

Private nurses have been in the past a most self-absorbed and indifferent body of women, thinking only of their personal aims and interests, caring little for their fellows. Those who have held hospital positions, especially hospital superintendents, being in constant touch with nursing affairs and seeing the abuses which need reform, have been the pioneers in all progressive movements and have labored almost alone. The alumnæ associations, growing in all directions, are beginning to get hold of the scattered private nurses and to arouse their interest, but all graduate nurses, in whatever walk in life, have opportunities which should appeal to them-responsibilities which they should not shirk.

We are said to be heirs of the ages. Trained nurses of to-day are heirs of very difficult pioneer work, done by a band of energetic, efficient workers whose toil has been so effective that what would seem to require a century to bring about has been done in a third of that time. We come into line and find modern hospitals, well equipped, with trainingschools attached, where nurses are taught in both theoretical and practical work. Are we to drink in all the knowledge offered us and devote the strength derived therefrom to concerns which affect ourselves alone? To do this is to miss the opportunity of doing our share of the world's work and results in narrowness and in imperfect development. It is most exasperating to the leaders in any line of work to see about them those who could be their helpers but who will not exert themselves. These are they who sit back and criticise the often faulty work done by others. Perhaps the work is faulty through lack of help which they could have given. Perhaps they think that if their own personal work is well done they have fulfilled their duty. They fail to realize that those who are not helping are hindering; that affairs of moment which will affect them personally in time are hanging in the balance, and that the influence of each person counts in the final turning of the scale.

Emerson says: "If you act, you show character; if you sit still, you show it. You think because you have spoken nothing when others spoke, and have given no opinion on the times, $\therefore$ t-your verdict is still expected with curiosity as a reserved wisdom. 1 ur otherwise; your silence answers very loud. You have no oracle to utter, and your fellowmen have learned that you cannot help them."

There is a class of beings, not intentionally lazy or selfish, but of a timid, retiring disposition, who think they are unfitted by nature to 
"speak in meeting" or to write papers, and that therefore they are of no value and must be counted out.

Yet these services, though conspicuous, are not the most useful. The nurse who thinks and reads and gains a clear idea of the standards for which we are striving is a help. She who in her daily life improves the opportunities of talking with and interesting other. nurses is a help. To one who is alert many occasions will arise in which she may be of service, and she may, by her presence and interest, be of aid in meetings in which she takes no active part.

I wish I could tell at length the story of a member of my own Alumnæ Association, one of the " quiet sort." She is married, she is in ill-health, she is an exile from home-excellent excuses for dropping out of sight; yet every alumnæ officer, every nurse-acquaintance, feels the inspiration which comes from her eager interest and unswerving loyalty. She is the kind of person who never forgets when her dues should be paid, who does not neglect to send in any change in her address, who responds promptly to any appeal made to our members in general. When our new nursing journal was contemplated, and we realized that it must have a goodly number of subscribers to make a start, she, in a land of strangers, secured five subscriptions. Do these things seem trifles? They are the trifles which count. An alumnæ association whose members were all animated by her spirit could work wonders.

I once heard an enthusiastic young minister, speaking of missions to some college students, say: "When we get to the Heavenly Jerusalem and hang our battered armor on the jasper walls and look back on the conflicts we have been waging, we shall say, 'I'm glad I was in that battle." How is it with us? When the first number of our nursing journal appeared, those who had wrestled with the problem of getting it started, those who had given what they could to help establish it, those who had written for it, those who had skirmished for subscribers for it, could look upon it with joy and pride and say: "I am glad I was in that battle." When the army nursing bill had been passed by Congress, those who had seen ills in the nursing service and had striven to remedy them, those who had borne unpleasant testimony for conscience's sake, those who had worked early and late to rouse interest in the measure, could give a sigh of relief and say: I am glad I was in that battle."

Shall we fold our hands while others do the fighting? No! The battle is still on. Let us be thankful that the interesting part of the struggle is not over and that we may have a hand in it. Let us try to earn the right to enjoy the glow of pleasure which comes, when the battle is over, to those who have helped win the victory. 